\title{
Variasi Morfologi Floral Anggota Suku Leguminosae Subsuku Lotoideae
}

\author{
Zuchrotus Salamah \\ Progam Studi Pendidikan Biologi, Universitas Ahmad Dahlan \\ Kampus III, Jl. Prof. Dr. Soepomo, SH, Yogyakarta, 55164 Indonesia \\ surat elektronik: szuchrotus@yahoo.com
}

\begin{abstract}
ABSTRAK
Penelitian ini menarik untuk dilakukan karena sangat bervariasinya suku Leguminosae dimana salah satu subsukunya adalah Lotoideae. Struktur morfologi bunga dari anggota subsuku digunakan sebagai karakter state dalam membedakan anggota-anggotanya. Tujuan dari penelitian ini adalah untuk mengetahui variasi morfologi floral vegetatif anggota subsuku Lotoideae serta untuk mengetahui variasi morfologi floral generatif anggota subsuku Lotoideae.

Metode yang digunakan adalah eksplorasi ke Yogjakarta dan sekitarnya untuk mencari bunga tanaman anggota subsuku Lotoideae, kemudian dilakukan pengamatan terhadap struktur morfologi floralnya, baik vegetatif maupun generatif. Selain itu juga dilakukan pengamatan terhadap morfologi serbuk sari yang sebelumnya telah dibuat preparat dengan menggunaan metode asetolisis. Data yang diperoleh berupa hasil pengukuran berbagai parameter bunga seperti petala, sepala, benangsari, serbuk sari, androecium, gynaecium, dan data hasil pengukuran serbuk sari dianalisis secara deskriptif.

Hasil dari penelitian ini adalah Variasi morfologi floral vegetatif anggota sub-suku Lotoideae yaitu memiliki kelopak yang berbeda pada ukurannya sedangkan persamaannya berjumlah 5, aestivationya berlekatan. Perbedaan mahkotanya adalah pada warna dan ukuran dari masing-masing bagian bunga,sedangkan persamaannya terdiri atas 5 petala, bentuknya menyerupai kupu-kupu, Bentuk mahkotanya terbagi 3 yaitu, bendera di bagian terluar merupakan bagian yang terlebar, sayap dengan ujung runcing dan lunas yang saling berlekatan berbentuk seperti sekoci. Variasi morfologi floral generatif anggota subsuku Lotoideae yaitu memiliki perbedaan pada jumlah berkas. Persamaan benangsarinya berjumlah I0, dan tersusun dalam berkas. Gynaecium perbedaannya adalah pada ukuran dan warna, sedangkan persamaannya adalah posisi ovarium menumpang, jumlah carpel I, plasentasi marginal, Aestivatio bebas. Ciri pada serbuksarinya berbeda dalam ukuran, aperture dan ornamentasi eksin sedangkan persamaannya adalah pada unit serbuk sari, simetri dan bentuknya.
\end{abstract}

Kata kunci: Morfologi nbFloral, Leguminosae, Lotoideae

\section{Pendahuluan}

Pada tumbuhan berbunga, keanekaragaman struktur floral telah berkembang sedemikian rupa. Keanekaragaman sifat ini berpengaruh langsung terhadap keberhasilan reproduksinya yang disesuaikan dengan berbagai cara polinasinya (Sa'nchezs, 2002), karena akan mempengaruhi tingkat atraktivitas terhadap pollinator dan efisiensinya sampai ke kepala putik. Morfologi floral yang berpengaruh terhadap keberhasilan reproduksi generatif terbentuk selama perkembangan waktu evolusi dan spesiasi masing-masing tumbuhan (Sanches, et al., 1997).

Suku Leguminosae merupakan salah satu golongan tumbuhan berbunga yang memiliki anggota sangat luas yang bervariasi strukturnya. Secara umum suku ini dicirikan karena memiliki struktur buah bertipe polongan (legume). Dalam sistem klasifikasi Wettstein 1934, suku Leguminosae dibagi menjadi tiga subsuku berdasar pada morfologi floralnya. Ketiga subsuku tersebut adalah Caesalpinoideae, yang dicirikan struktur aestivasi petalnya yang imbrikata naik, subsuku Mimosoideae yang memiliki inflorescentia capitulum, dan subsuku Lotoideae yang memiliki struktur aestivasi petal imbrikata turun dan cenderung berbentuk papilion atau seperti kupu-kupu, sehingga pada beberapa sistem klasifikasi dibuatkan suku tersendiri yaitu Papilionaceae.

Satu hal yang menarik pada subsuku Lotoideae adalah keanekaragaman morfologi floralnya, yang terdiri atas floral vegetatif dan flora generatif. Floral vegetatif terdiri atas kelopak yang memiliki beberapa daun kelopak (sepala) serta mahkota atau corolla yang terdiri 
atas beberapa daun mahkota (petala). Floral generative merupakan bagian bunga yang berhubungan dengan kelaminnya meliputi benang sari, serbuk sari dan putik. Walaupun secara umum pada subsuku ini memiliki susunan petal seperti kupu-kupu, tetapi ada variasivariasi khas untuk tiap-tiap spesiesnya. Keanekaragaman variasi dapat dijumpai pada berbagai bagian floral, antara lain inflorescentia, keanakeragaman bagian petalanya : vexilum, alae, dan carina, serta jumlah berkas androecium organ kelamin jantannya. Selain itu benangsari juga merupakan bagian penting yang perlu untuk dikaji karena merupakan alat kelamin jantan tumbuhan dan memiliki ragam morfologi sel kelamin jantan (serbuk sari) yang unik.

Serbuk sari merupakan hal penting dalam taksonomi karena dapat dipakai sebagai sarana identifikasi tumbuh-tumbuhan dengan mengamati ciri dan sifat dari morfologi serbuk sari. Kajian morfologi yang menentukan sifat-sifat serbuk sari yaitu: bentuk serbuk sari, unit serbuk sari, ukuran serbuk sari, tipe apertura, struktur dan ornamentasi eksinnya, polaritas, dan simetri. Keunikan serbuk sari tersebut dapat dilihat setelah membuat preparat serbuk sari dengan menggunakan metode asetolisis terlebih dahulu, semua ornament yang ada di permukaan serbuk sari akan terlihat dengan jelas.

Oleh karena itu sangat menarik untuk mengkaji variasi struktur floral vegetatif dan generatif pada subsuku Lotoideae ini untuk diketahui sampai seberapa jauh keanekaragaman variasi pada beberapa spesies yang sudah akrab di kehidupan kita, antara lain : Crotalaria sp, Glirsidia sepium, Vigna sinensis, Canavalia sp., Sesbania grandifolia, Erytrina cristagali, Clitoria ternatea

Tujuan Penelitian ini untuk ntuk mengetahui variasi morfologi floral vegetatif anggota subsuku Lotoideae dan mengetahui variasi morfologi floral generatif anggota subsuku Lotoideae. Manfaat dari penelitian ini antara lain dapat memberi wawasan keilmuan dan informasi bagi berbagai fihak untuk meneliti lebih lanjut - Sebagai upaya pengembangan sumber belajar tentang tumbuhan yang dapat digunakan pada tingkat sekolah menengah. Sebagai eksplorasi positip terhadap kekayaan sumber alam hayati di Indonesia.

\section{Metode Penelitian}

Alat yang digunakan dalam penelitian ini meliputi : cawan petri, seperangkat Mikroskop , optilab, loup, lampu, kamera, botol flakon tabung reaksi tabung sentrifus, vortex, waterbath, gelas benda dan gelas penutup (desk glasser) untuk mikrometer (okuler mikrometer dan obyek mikrometer) batang gelas atau pengaduk, petridish, erlenmeyer, lampu spirtus, penjepit kayu, pisau cutter, gunting, pipet tetes, korek api.

Bahan yang digunakan antara lain : bahannya adalah bunga dari 7 jenis tanaman anggota subsuku Lotoideae yg terdapat di daerah kota Yogyakarta dan sekitarnya serta Bantul, asam asetat glasial, asam sulfat pekat dengan perbandingan $9: 1$, aquades, safranin 0,0I\% yang dipakai untuk pewarnaan, gliserin jeli, lilin, tisu dan kertas aluminium foil. Adapun macam spesiesnya adalah Crotalaria sp, Glirisidia sepium, Vigna sinensis, Canavalia sp., Sesbania grandifolia, Erytrina cristagali, Clitoria ternatea

\section{Pengumpulan dan Penyiapan Bahan}

Dilakukan eksplorasi berbagai jenis tanaman anggota subsuku Lotoideae yang terdapat di daerah kota Yogyakarta dan sekitarnya serta Bantul.

\section{Pengamatan terhadap Bunga}

Bunga dari tanaman anggota subsuku Lotoideae diamati berbagai sifat dan cirinya pada bagian floral vegetatifnya antara lain adalah jumlah, ukuran, warna, aestivasi dari kelopak. Pada bagian mahkotanya yang diamati adalah jumlah, ukuran, warna, aestivasi, bentuk daun-daun mahkotanya, Sedangkan sifat dan cirri morfologi floral generatif yang diamati adalah : benangsari yang diamati adalah jumlah benangsari dalam satu bunga, panjang tangkai sari, jumah berkas, dan jumlah benangsari dalam masing 2 berkas. Putik yang diamati adalah ukuran gynaecium, posisi ovarium, jumlah carpel, aestivasi dan plasentasi. Selain data morfologi floral vegetatif dan generatif dibuat juga rumus bunganya. Jumlah bunga yang diamati lebih kurang 20 buah.

\section{Pembuatan Preparat Serbuk Sari dan pengamatannya}

Pembuatan preparat serbuk sari dengan menggunakan metode asetolisis (Soerodikoesumo, 1987), dan pengamatan morfologi serbuk sari dilakukan dengan menggunakan mikroskop, optilab serta pengukurannya dilakukan dengan menggunakan micrometer.

\section{Analisis Data}

Data dari penelitian ini berupa hasil pengamatan secara morfologis berupa foto-foto kajian morfologi baik floral vegetatif maupun generatif dianalisis secara deskriptif untuk mencari perbedaan dan persamannya. Data morfologi serbuk sari dianalisis secara deskriptif kuantitatif.

\section{Hasil dan Pembahasan}

\section{Hasil Pengamatan Morfologi Floral}

Dalam penelitian ini diamati 7 spesies anggota subsuku Lotoidea yang dijumpai di Yogyakarta dan sekitarnya. Ketujuh spesies tersebut adalah Crotalaria sp, Glirsidia sepium, Vigna sinensis, Canavalia sp., Sesbania grandifolia, Erytrina cristagali, Clitoria tematea. Hasil yang diamati berupa ciri morfologi dari bunga meliputi floral vegetatif yaitu kelopak dan mahkotanya serta floral generatif meliputi benangsari, serbuk sari dan putiknya. Hasil selengkapnya adalah sebagai berikut:

\section{Crotalaria sp}

Crotalaria memiliki bunga dengan kelopak berjumlah 5 , ukurannya $(\mathrm{p} / 1)$ adalah $(0,60 \pm 0,02) \mathrm{cm}$, 
warnanya hijau muda, aestivationya berlekatan. Mahkota bunganya terdiri atas petala yang berjumlah lima, masing-masing berukuran Bendera = $(1,68 \pm 0,06) \mathrm{cm}$, Sayap $=(2,96 \pm 0,12) \mathrm{cm}$, Lunas $=(1,29 \pm 0,04) \mathrm{cm}$. Warna kuning kombinasi garisgaris vertikal berwarna ungu. Aestivatio bendera I di bagian terluar, sayap 2 berlepasan ada di sebelah dalam bendera di kanan kirinya, lunas 2 berlekatan terletak di sebelah salam sayap. Bentuk petalanya terbagi 3 yaitu, bendera di bagian teruar merupakan bagian yang terlebar, sayap dengan ujung runcing dan lunas yang saling berlekatan berbentuk seperti sekoci.

Untuk androecium Crotalaria jumlahnya I0, ukuran panjangnya $(\mathrm{I}, 56 \pm 0,02) \mathrm{cm}$, jumlah berkas I (monadelpus), jadi kesepuluh benangsari dalam satu berkas yang saling berlekatan pada bagian filamennya. Gynaecium panjangnya $(1,73 \pm 0,02) \mathrm{cm}$, posisi menumpang, jumlah karpelnya I, aestivatio bebas,

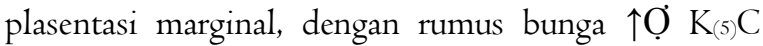
${ }_{\mathrm{I}, 2,(2)} \mathrm{A}_{(\mathrm{I})} \mathrm{G}_{\mathrm{I}}$.

\section{Gliciridia sepium}

Kelopak terdiri atas sepala berjumlah 5, ukurannya $(0,36 \pm 0,0 \mathrm{I}) \mathrm{cm}$, warna merah muda keunguan sampai ungu tua, aestivatio berlekatan. Mahkota terdiri atas petala jumlahnya 5, ukurannya masing-masing Bendera $=(\mathrm{I}, \mathrm{I} 7 \pm 0,02) \mathrm{cm}$, Sayap $=(2,93 \pm 0,09) \mathrm{cm}$, Lunas $=(1,89 \pm 0,06) \mathrm{cm}$. Warna merah muda sampai putih keunguan, tetapi benderanya berwarna merah muda dengan kombinasi kuning pada bagian tengahnya. Aestivatio bendera I di bagian terluar, sayap 2 berlepasan ada di sebelah dalam bendera terdapat di kanan kiri, lunas 2 berlekatan terletak di sebelah dalam sayap. Bentuk petalanya terbagi menjadi 3 bentuk yaitu, bendera di bagian terluar merupakan bagian terlebar, sayap dengan ujung runcing dan lunas yang saling berlekatan berbentuk seperti sekoci.

Androecium jumlahnya I0, ukuran panjangnya (I,75 $\pm 0,04) \mathrm{cm}$, jumlah berkas 2 (diadelphous), Jumlah masing-masing berkasnya adalah 9 stamen saling berlekatan pada bagian filamen membentuk I berkas dan I stamen bebas dalam berkas tersendiri.

Gynaecium, panjang $(\mathrm{I}, 95 \pm 0,02) \mathrm{cm}$, posisi ovarium menumpang, jumlah carpelnya I, aestivatio bebas, plasentasi marginal, warna ungu tua. Rumus bunganya $\uparrow O ̛$ K $\mathrm{K}_{(5)} \mathrm{C}_{\mathrm{I}, 2,(2)} \mathrm{A}_{(9)+\mathrm{I}} \mathrm{G}_{\text {I. }}$.

\section{Vigna sinensis}

Kelopak terdiri atas 5 sepala, ukuran $(0,83 \pm 0,03) \mathrm{cm}$, warna hijau muda, aestivatio berlekatan. Mahkota terdiri atas petala jumlahnya 5, ukuran bendera $=(0,98 \pm 0,02) \mathrm{cm}$, sayap $=(2,10 \pm 0,05) \mathrm{cm}$, lunas $=(1,05 \pm 0,02) \mathrm{cm}$, bendera berwarna ungu, sayap ungu tua dan lunas putih, bendera I di bagian terluar, sayap (2) berlepasan ada di sebelah dalam bendera terdapat di kanan kiri, lunas (2) berlekatan terletak di sebelah dalam sayap, bentuk petalanya terbagi menjadi 3 bentuk yaitu, bendera di bagian terluar merupakan bagian terlebar, sayap dengan ujung runcing dan lunas yang saling berlekatan berbentuk seperti sekoci.

Androecium, jumlah I0, ukuran panjang (3,02 $\pm 0,06) \mathrm{cm}$, jumlah berkas 2 (diadelphous), jumlah masing-masing berkas 9 stamen saling berlekatan pada bagian filamen membentuk I berkas dan I stamen bebas dalam berkas tersendiri.

Gynaecium, panjang $(3,29 \pm 0,06) \mathrm{cm}$, Posisi ovarium Menumpang, aestivatio bebas, plasentasi marginal, ciri pangkal dari ovariumnya berbulu, rumus bunganya $\uparrow O ̛$ ( $\mathrm{K}_{(5)} \mathrm{C}_{\mathrm{I}, 2,(2)} \mathrm{A}_{(\vartheta)+\mathrm{I}} \mathrm{G}_{\text {I }}$.

\section{Canavalia sp.}

Kelopak terdiri atas 5 sepala, ukuran $\mathrm{p} / 1$ $(0,67 \pm 0,0 \mathrm{I}) \mathrm{cm}$, warna hijau muda, aestivatio berlekatan, ciri terdapat brachtea 2 di kanan kiri dengan panjang $0,4 \mathrm{~cm}$ dan lebar $0,2 \mathrm{~cm}$. Mahkota terdiri atas petala jumlahnya 5, ukuran Bendera $=$ $(0,85 \pm 0,01) \mathrm{cm}$, Sayap $=(1,97 \pm 0,04) \mathrm{cm}$, Lunas $=(2,40 \pm 0,06) \mathrm{cm}$, warna mahkota putih, aestivatio bendera I di bagian terluar, sayap 2 berlepasan ada di sebelah dalam bendera terdapat di kanan kiri, lunas 2 berlekatan terletak di sebelah dalam sayap, Bentuk petalanya terbagi menjadi 3 bentuk yaitu, bendera di bagian terluar merupakan bagian terlebar, sayap dengan ujung runcing dan lunas yang saling berlekatan berbentuk seperti sekoci

Androecium jumlah IO, Ukuran panjang $(I, 82 \pm 0,04) \mathrm{cm}$, Jumlah berkas 2 (diadelphous), Jumlah masing-masing berkas 9 stamen saling berlekatan pada bagian filamen membentuk I berkas dan I stamen bebas dalam berkas tersendiri.

Gynaecium, Panjang $(2,12 \pm 0,03) \mathrm{cm}$, Posisi ovarium Menumpang, Jumlah carpel I, Aestivatio

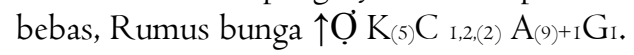

\section{Sesbania grandiflora}

Kelopak terdiri atas 5 sepala, ukuran $\mathrm{p} / 1$ $(0,70 \pm 0,03) \mathrm{cm}$, warna hijau muda, aestivatio berlekatan, mahkota terdiri atas petala jumlahnya 5, ukuran $\mathrm{p} / 1$ Bendera $=(1,62 \pm 0,03) \mathrm{cm}$, Sayap $=$ $(4,65 \pm 0, \mathrm{II}) \mathrm{cm}$, Lunas $=(2,52 \pm 0,02) \mathrm{cm}$, warna merah, aestivatio bendera I di bagian terluar, sayap 2 berlepasan ada di sebelah dalam bendera terdapat di kanan kiri, lunas 2 berlekatan terletak di sebelah dalam sayap. Bentuk petalanya terbagi menjadi 3 bentuk yaitu, bendera di bagian terluar merupakan bagian terlebar, sayap dengan ujung runcing dan lunas yang saling berlekatan berbentuk seperti sekoci.

Androecium jumlahnya I0,ukuran panjang (I0,0I $\pm 0,33) \mathrm{cm}$, jumlah berkas 2 (diadelphous), Jumlah masing-masing berkas 9 stamen saling berlekatan pada bagian filamen membentuk I berkas dan I stamen bebas dalam berkas tersendiri.

Gynaecium, Panjang $(10,87 \pm 0,47) \mathrm{cm}$, Posisi ovarium Menumpang, Jumlah carpel I, plasentasi 
marginal, Aestivatio bebas, Rumus bunga $\uparrow \mathrm{O}^{\circ} \mathrm{K}_{(5)} \mathrm{C}$ I,2,(2) $\mathrm{A}_{(9)+\mathrm{I}} \mathrm{G}_{\text {I. }}$

\section{Erythrina cristagali}

Kelopak terdiri atas 5 sepala, ukuran $\mathrm{p} / 1$ $(0,63 \pm 0,0 \mathrm{I}) \mathrm{cm}$, warna merah, aestivatio berlekatan. Mahkota terdiri atas petala jumlahnya 5 , ukuran $\mathrm{p} / 1$ bendera $=(I, 33 \pm 0,0 \mathrm{I}) \mathrm{cm}$, sayap $=(2,22 \pm 0,06) \mathrm{cm}$, lunas $=(1,45 \pm 0,02) \mathrm{cm}$. warna merah marun, aestivatio bendera I di bagian terluar, sayap 2 berlepasan ada di sebelah dalam bendera terdapat di kanan kiri, lunas 2 berlekatan terletak di sebelah dalam sayap. Bentuk petalanya terbagi menjadi 3 bentuk yaitu, bendera di bagian terluar merupakan bagian terlebar, sayap dengan ujung runcing dan lunas yang saling berlekatan berbentuk seperti sekoci.

Androecium, jumlah I0, ukuran panjang $(4,60 \pm 0,02) \mathrm{cm}$, jumlah berkas 2 (diadelphous), jumlah masing-masing berkas 9 stamen saling berlekatan pada bagian filamen membentuk I berkas dan I stamen bebas dalam berkas tersendiri.

Gynaecium, panjang $(4,47 \pm 0,03) \mathrm{cm}$, posisi ovarium Menumpang, Jumlah carpel I, plasentasi marginal, aestivatio bebas, Rumus bunga $\uparrow O^{\circ} \mathrm{K}_{(5)} \mathrm{C}$ I,2,(2) $\mathrm{A}_{(9)+1} \mathrm{G}_{\mathrm{I}}$.

\section{Clitoria ternatea}

Kelopak terdiri atas 5 sepala, ukuran $\mathrm{p} / 1$ $(\mathrm{I}, 2 \mathrm{I} \pm 0,03) \mathrm{cm}$, warna hijau, aestivation berlekatan, ciri terdapat brachtea 2 di kanan kiri dengan panjang I $\mathrm{cm}$ dan lebar I cm. Mahkota terdiri atas petala jumlahnya 5 , ukuran bendera $=(I, 29 \pm 0,03) \mathrm{cm}$, sayap $=(2,63 \pm 0,09) \mathrm{cm}$, lunas $=(2,13 \pm 0,06)$ $\mathrm{cm}$, aestivatio bendera I di bagian terluar, sayap 2 berlepasan ada di sebelah dalam bendera terdapat di kanan kiri, lunas 2 berlekatan terletak di sebelah dalam sayap, bentuk petalanya terbagi menjadi 3 bentuk yaitu, bendera di bagian terluar merupakan bagian terlebar, sayap dengan ujung runcing dan lunas yang saling berlekatan berbentuk seperti sekoci.

Androecium jumlah I0, ukuran $(\mathrm{I}, 88 \pm 0,03) \mathrm{cm}$, jumlah berkas 2 (diadelphous), Jumlah masing-masing berkas 9 stamen saling berlekatan pada bagian filamen membentuk I berkas dan I stamen bebas dalam berkas tersendiri

Gynaecium panjang $(2,30 \pm 0,06) \mathrm{cm}$, posisi ovarium menumpang, jumlah carpel I, aestivatio bebas, plasentasi marginal, rumus bunga adalah $\uparrow O ̛ ̣$ $\mathrm{K}_{(5)} \mathrm{C}_{1,2,(2)} \mathrm{A}_{(\vartheta)+\mathrm{I}} \mathrm{G}_{\mathrm{I}}$.

Dari hasil pengamatan yang ada maka dijumpai adanya perbedaan dan persamaan dalam ketujuh spesies anggota Lotoidea tersebut, dari floral vegetatif yaitu warnanya relatif sama yaitu hijau kecuali pada Erytrina yang berwarna merah, perbedaan yang ada adalah pada ukuran, semuanya memiliki kelopak yang berjumlah 5, aestivationya berlekatan. Perbedaan mahkotanya adalah pada warna dan ukuran dari masing-masing bagian bunga, sedangkan persamaan ciri mahkotanya terdiri atas 5 petala, yang bentuknya menyerupai kupu-kupu. Bentuk mahkotanya terbagi 3 yaitu, bendera di bagian terluar merupakan bagian yang terlebar, sayap dengan ujung runcing dan lunas yang saling berlekatan berbentuk seperti sekoci.

Untuk floral generatif bagian yang diamati meliputi benangsari dan putiknya. Dalam penelitian ini hanya Crotalaria yang kesepuluh benangsarinya tersusun dalam I berkas (monadelphous). Perbedaan lainnya dari benangsari adalah ukuran panjang tangkai sarinya bervariasi. Persamaan dari benangsarinya adalah jumlahnya $\mathrm{IO}$, tersusun dalam dua berkas (diadelphous), jumlah masing-masing berkas 9 stamen saling berlekatan pada bagian filamen membentuk I berkas dan I stamen bebas dalam berkas tersendiri. Ciri dari Gynaecium perbedaannya adalah pada ukuran dan warna, persamaannya adalah posisi ovarium menumpang, jumlah carpel I, plasentasi marginal, Aestivatio bebas.

Dari ketujuh jenis yang diamati semuanya memiliki persamaan yang sangat spesifik sebagai kelompok Lotoideae yaitu mahkota bunga terdiri lima petala, yang terbagi atas satu bendera dengan ukuran relatif besar bila dibandingkan dengan petala lainnya, dua petala ada di bagian samping dengan ukuran sama, dan dua petala lagi di bagian bawah sebagai carina atau lunas, ukuran sayap dan carina bervariasi bisa saja lebih besar sayapnya atau lebih besar carinanya seperti pada Erytrina yang memiliki sayap berukuan kecil dan tertutup posisinya oleh carina. Oleh karena bentuk mahkota yang menyerupai kupu-kupu maka kelompok ini juga dikenal sebagai Papilionaceae.

\section{Hasil pengamatan serbuk sari}

Serbuk sari merupakan sel kelamin jantan yang terdapat dalam kepala sari dengan jumlah di masingmasing kepala sari dapat mencapai ribuan. Serbuk sari mempunyai karakter yang sangat spesifik untuk masingmasing spesies sesuai dengan jenisnya, selain itu bentuk serbuk sari seringkali juga ditentukan oleh bagaimana cara penyerbukannya atau dengan bantuan apa serbuk sari itu dapat jatuh di atas kepala putik.

Anggota subsuku Lotoideae memiliki bunga berbentuk kupu-kupu, benangsarinya tersusun dalam berkas, ada yang memiliki satu berkas dan ada pula yang memiliki dua berkas. Ukurannya bervariasi, namun bila dilihat dengan seksama maka tangkai sarinya panjang, hal ini akan mempengaruhi terjadinya penyerbukan. Bunga ini kebanyakan penyerbukannya dibantu oleh serangga, hal ini akan sangat menentukan dalam hal ukuran serbuk sarinya. Walker (Aprianty, 2008) menyatakan bahwa serbuk sari merupakan alat penyebaran dan perbanyakan generatif dari tumbuhan berbunga. Secara sitologis, serbuk sari merupakan sel dengan tiga nukleus, yang masing-masing dinamakan inti vegetatif, inti generatif I dan inti generatif II. Sel dalam serbuk sari dilindungi oleh dua lapisan (disebut intine 
untuk yang di dalam dan exine yang bagian luar), untuk mencegahnya mengalami dehidrasi. Serbuk sari memiliki peran untuk membuahi sel telur apabila jatuh di atas kepala putik dan akan membentuk buluh serbuk sari sehingga inti sperma dapat mencapai sel telur, hanya sperma yang secara genetik sesuai dengan sel telur yang akan dapat membuahinya. Serbuk sari memiliki bentuk dan ornamentasi yang bervariasi, pada umumnya dalam satu golongan seperti suku ataupun subsuku akan memiliki beberapa persamaan ciri.

Bentuk serbuk sari dapat kelihatan dengan jelas setelah serbuk sari dibuat preparat dengan menggunakan metode asetolisis, dengan metode ini memungkinkan struktur permukaan serbuk sari terlihat dengan jelas. Beberapa larutan asam diberikan pada saat pembuatan preparat akan menyebabkan lapisan permukaan serbuk sari akan lebih jelas terlihat detilnya. Permukaan serbuk sari ada yang halus tanpa ornament dan ada pula yang permukaannya tidak halus. Pada Lotoideae ini ternyata tidak memiliki ornament yang tajam seperti papilla atau tonjolan (seperti pada serbuk sari Malvaceae dan Asteraceae), jika ada ornament maka bentuknya cenderung tipis dan kecil. Pada Crotalaria, Glirisidia, Canavalia dan Clitoria serbuk sari tampak halus tanpa ornament. Pada Vigna dan Erythrina tampak memiliki ornament yang sama yaitu retikulat, dimana ornament ini tampak seperti jala, sedangkan pada Sesbania tampak serbuk sarinya tidak halus dengan tipe verukat. Bila dilihat dari sisi ornamennya ternyata dijumpai adanya variasi walaupun ke tujuh spesies ini masuk dalam subsuku yang sama.

Berdasarkan hasil pengamatan dan pengukuran dari ketujuh anggota Lotoideae yang diamati ternyata menunjukkan adanya perbedaan dalam ukuran, aperture dan ornamentasi eksin serbuk sarinya. Indeks P/E dan Sumbu Terpanjang serbuk sari dalam $\mu \mathrm{m}$ juga menunjukkan adanya variasi.

Panjang aksis polar (P) dan diameter bidang equatorial (E) serbuk sari diukur dengan menggunakan mikrometri, sehingga diperoleh indeks polar/ekuatorial. Hasil rata-rata perhitungan dianalisa dengan mencari standart errornya. Hasil pengukuran indeks $\mathrm{P} / \mathrm{E}$ menunjukkan bahwa Clitoria memiliki ukuran terbesar bila dibandingkan dengan serbuk sari lainnya. Jadi dapat dikatakan bahwa antara satu jenis tumbuhan dengan jenis tumbuhan lain dapat terletak pada ukuran butir pollen. Pada subsuku Lotoideae ini ternyata ukuran serbuk sarinya termasuk kecil, sedang dan besar. Ukuran serbuk sari bervariasi antara $5 \mu \mathrm{m}$ sampai lebih dari $200 \mu \mathrm{m}$, akan tetapi kebanyakan berkisar antara $20 \mu \mathrm{m}$ sampai dengan $50 \mu \mathrm{m}$. Besarnya butir serbuk sari apabila dianalisa menggunakan pendapat Erdtman (I954), maka ukurannya rata-rata ada pada peringkat sedang yaitu antara 25 - 50 $\mathrm{m}$, yaitu pada Gliciridia, Canavalia, Sesbania, dan Erythrina, sedangkan pada Vigna $(77,83 \pm \mathrm{I}, 54) \mu \mathrm{m}$ dan Clitoria $(68,37 \pm 3,53) \mu \mathrm{m}$ berukuran besar. Crotalaria serbuk sarinya berukuran kecil, yaitu (19,99 $\pm 0,66) \mu \mathrm{m}$.

Apertura serbuk sari secara umum tipenya adalah triporat, trikolkolpat, dan akolpat. Sedangkan tipe ornamentasinya adalah psilat, retikulat dan skabrat. Erdtman (Aprianty,2008) menyebutkan bentuk, ukuran maupun tipe pollen bisa bervariasi menurut tahap kematangannya. Tahap kematangan ini dapat dilihat dengan cara membuat preparat serbuk sari pada berbagai tahap perkembangannya yang dikenal dengan istilah mikrosporogenesis. Dalam penelitian ini semua serbuk sari diambil dari bunga yang sudah mekar sehingga diharapkan serbuk sari berada dalam tahap yang sama, yaitu tahap akhir dan siap untuk membuahi. Pada ketujuh spesies anggota Lotoideae ini memiliki aperture dengan tipe porat dan kolpat. Porus biasanya mempunyai bentuk sedikit memanjang tetapi dengan berakhir melingkar (membulat). Sedangkan kolpus adalah celah panjang dan berbentuk perahu. Butir serbuk sari dengan kolpus disebut kolpat dan butir dengan porus disebut porat. Pada Canavalia, Sesbania memiliki tipe kolpat sedangkan yang lainnya bertipe porat.

Berdasarkan hasil pengamatan dan pengukuran dari ketujuh anggota Lotoideae yang diamati ternyata menunjukkan adanya persamaan. Persamaan ketujuh spesies tersebut adalah semuanya monad dimana unit serbuk sari ditentukan dengan menghitung jumlah butir serbuk sari dalam satu unit serbuk sari (Erdtman, I954), disebut Monad karena satu unit serbuk sari dengan butir serbuk sari yang tunggal. Persamaan lainnya adalah bentuknya yang subsferoidal berdasarkan indeks $\mathrm{P} / \mathrm{E}$ serbuk sarinya yang berkisar 0,75-I,33 . Serbuk sari ketujuh spesies anggota Lotoideae bila dilihat simetrinya memiliki simetri radial dimana serbuk sarinya dapat dibagi menjadi dua bagian yang sama dengan lebih dari dua bidang atau banyak bidang simetri.

Secara keseluruhan terdapat adanya variasi morfologi floral anggota suku Leguminosae subsuku Lotoideae, variasi tersebut ditunjukkan dengan adanya perbedaan ciri seperti warna, bentuk, ukuran. Sebagai penentu dimasukkannya suatu spesies ke dalam suatu takson adalah anggota subsuku ini memang mempunyai ciri yang sama yaitu pada struktur mahkota yang terdiri 5 petala dengan bentuk bervariasi yang disebut sebagai bendera, sayap dan lunas. Demikian pula halnya dengan serbuk sarinya yang terdiri dari satu unit serbuk sari yang disebut monad.

\section{Simpulan}

Berdasarkan hasil pembahasan maka dapat disimpulkan bahwa variasi morfologi floral vegetatif anggota sub-suku Lotoideae yaitu memiliki kelopak yang berbeda pada ukurannya sedangkan persamaannya berjumlah 5, aestivationya berlekatan. Perbedaan mahkotanya adalah pada warna dan ukuran dari masingmasing bagian bunga, sedangkan persamaan mahkotanya 
terdiri atas 5 petala, yang bentuknya menyerupai kupukupu, Bentuk mahkotanya terbagi 3 yaitu, bendera di bagian teruar merupakan bagian yang terlebar, sayap dengan ujung runcing dan lunas yang saling berlekatan berbentuk seperti sekoci. Variasi morfologi floral generatif anggota subsuku Lotoideae yaitu memiliki perbedaan pada jumlah berkas. Persamaan benangsarinya berjumlah I0, dan tersusun dalam berkas. Gynaecium perbedaannya adalah pada ukuran dan warna, sedangkan persamaannya adalah posisi ovarium menumpang, jumlah carpel I, plasentasi marginal, Aestivatio bebas. Ciri pada serbuksarinya berbeda dalam ukuran, aperture dan ornamentasi eksin sedangkan persamaannya adalah pada unit serbuk sari, simetri dan bentuknya.

\section{Daftar Pustaka}

Aprianty dan Eniek Kriswyanti, 2008, Studi Variasi Ukuran Serbuk Sari Kembang Sepatu (Hibiscus rosa-sinensis) dengan Warna Bunga Berbeda. Jurnal Biologi XII(I): I4I8. ISSN: I4I05292

Erdtman, G. 1954. An Introduction to Pollen Analysis. The Chronica Botanica Co. Waltham Mass. USA.

Sa'nchez, Lafuente, 2002, Floral Variation in The Generalist Perennial Herb Paeonia bronteroi (Paeoniaceae): Differences Between Region with Different Pollinators and Herbivores. American Journal of Botany 89(8): I260-I269. 2002

Sanchez, Javier Guitian, Pablo Guitian, Monica Medrano 1997, Variation in Floral Morphology and Individual Fecundity in Erythvonium dens-canis (Liliaceae). Ecography 22: 708 714. Copenhagen 1999

Soerodikoesoemo, W. 1987. Petunjuk Praktikum Mikroteknik Tumbuhan. Fakultas Biologi Universitas Gadjah Mada. Yogyakarta. 